28

\title{
LESSONS LEARNED FROM FOUR HIGH-CASUALTY TERRORIST ATTACKS IN THE UNITED STATES SINCE 9/11
}

\author{
Paul Cruickshank
}

Almost two decades after 9/11, the United States has suffered four high-casualty Islamist terrorist attacks: the Fort Hood shooting in November 2009, the Boston Marathon bombings in April 2013, the San Bernardino attack in December 2015, and the Orlando nightclub shooting in June 2016. These attacks killed 80 people and injured almost $400 .^{1}$

This chapter tells the story about how the four attacks slipped through the cracks of the U.S. security apparatus and how, with the benefit of hindsight, warning signs were missed. In three of the plots (Fort Hood, Boston, and Orlando), the Federal Bureau of Investigation (FBI) previously had the perpetrator, or one of the perpetrators, on their radar for suspected terrorism-related activity. Official reviews have identified shortcomings in investigative protocols, management of leads, training, access to databases, information sharing, and human error.

Given the scale of the counterterrorism challenge faced by U.S. security agencies, and the difficult judgment calls they must continuously make on which probes to prioritize, the aim of this chapter is not to assign blame but to provide an overview of each case so that lessons can be learned. ${ }^{2}$

\section{The Fort Hood shooting}

Shortly after 1:30 PM on November 5, 2009, Major Nidal Malik Hasan, a 39-year-old Army psychiatrist who was soon due to deploy to Afghanistan, entered the Soldier Readiness Center at Fort Hood, Texas, with two guns, including an FN Five-seveN semi-automatic pistol, shouted the words "Allahu Akhbar" (God is Great), and began shooting. Singling out unarmed U.S. soldiers, Hasan killed 13 and injured an additional 32 people before civilian police shot and incapacitated him. In 2013, a military tribunal convicted Hasan and sentenced him to death. ${ }^{3}$

\section{Genesis of the plot}

Hasan, the son of Palestinian immigrants, began active duty in the Army in 1995. In the years after 9/11, Hasan transformed from a devout Muslim to embracing Islamist extremist views. These were on full display by 2007 when fellow officers at the U.S. Army's Walter Reed Medical Center in Maryland described him as having "fixed radical beliefs about fundamentalist Islam" that he shared at "every possible opportunity." 
During the same period, Hasan warned in writings several times that Muslim-Americans in the military could be prone to fratricide. ${ }^{5}$ At Walter Reed, Hasan had been exposed to soldiers traumatized by conflict in Iraq and Afghanistan, making it possible this later contributed to how he reacted when he received deployment orders.

Between December 2008 and June 2009, Hasan and Anwar al-Awlaqi, a Yemeni-American jihadi cleric based in Yemen, exchanged 18 e-mails focusing on a variety of issues, including the permissibility of suicide bombings. Hasan initiated 16 of the 18 e-mails. He was clearly in awe of the cleric, who previously led prayers at a mosque in Falls Church, Virginia, around 2001. ${ }^{6}$ During the course of their correspondence, Hasan wrote that they had met briefly when al-Awlaqi was the imam at the mosque but "I doubt if you remember me." In an e-mail in February 2009, Hasan spoke of paradise but did not appear to have necessarily envisaged carrying out an attack at that time because he told al-Awlaqi he wanted to find a wife. ${ }^{8}$

By the time the communications began, al-Awlaqi had already been publicly described by a Department of Homeland Security official as an "example of al-Qaida reach into the Homeland." Al-Awlaqi, who communicated with many followers around the world from Yemen, only sent Hasan two short and benign replies..$^{10}$ No evidence has emerged that the cleric directly encouraged or instructed Hasan to carry out an attack. In an interview with a Yemeni journalist shortly after the Fort Hood shooting, al-Awlaqi stated that while the attack was "permissible," he neither ordered nor pressured Hasan to harm Americans. ${ }^{11}$

While al-Awlaqi did not explicitly and publicly call for jihad against the United States until several months after the Fort Hood shootings, the cleric had for years released audio sermons supportive of al-Qaida's worldview, which likely influenced Hasan. ${ }^{12}$ Several days after Hasan's gun rampage, al-Awlaqi wrote on his blog that Hasan was a "hero [and a] man of conscience who could not bear living the contradiction of being a Muslim and serving in an army that is fighting against his own people." ${ }^{13}$

It is not clear exactly when Hasan began contemplating an attack, but he purchased the weapon he used in the shooting on August 1, 2009, after asking for the "most high-tech handgun" available at a gun store near the military base. In October 2009, the Army notified him that he would deploy to Afghanistan in November. It is possible this news served as the trigger for his attack. No evidence has emerged that Hasan told anyone ahead of time of his plans. ${ }^{14}$

\section{Missed warning signs?}

With the benefit of hindsight, there were two missed opportunities to identify Hasan as a serious threat. First, the Department of Defense failed to sufficiently examine obvious signs of radicalization. Second, the FBI could have scrutinized Hasan more intensively following discovery of his communications with al-Awlaqi.

\section{Signs of radicalization at Walter Reed}

According to a 2011 Senate Homeland Security Committee report into the shooting, Hasan's "radicalization to violent Islamist extremism came into plain view" while he studied and worked at Walter Reed Army Medical Center in Maryland from 2006-2008. He spoke favorably of suicide bombings and wrote in support of some of the actions of Usama bin Ladin and in one class caused such offense that one of his presentations had to be stopped. Hasan's superior officers received reports several times about his extremist utterances, yet "they failed to discipline him, refer him to counterintelligence officials or seek to discharge him." Instead, he was promoted to major in May 2009. In July 2009, Hasan was transferred from Walter Reed to Fort Hood, Texas, the Army's staging area for deployment to combat zones. ${ }^{15}$ 


\section{Paul Cruickshank}

\section{Communications with Anwar al-Awlaqi}

Hasan's communications with Anwar al-Awlaqi marked a second warning sign. As part of a continuing investigation into al-Awlaqi, the FBI monitored a large volume of online message traffic to/from the cleric as a "trip wire" for identifying persons of potential interest. ${ }^{16}$ On December 17, 2008, Hasan tripped the wire when he visited al-Awlaqi's website and sent him a first message, asking whether Muslim-American soldiers who died while killing, or trying to kill, their fellow soldiers to help Muslims fighting jihad were shaheeds (martyrs). ${ }^{17}$

Members of the Joint Terrorism Task Force (JTTF) in the FBI's San Diego Field Office, who were in charge of investigating al-Awlaqi, reviewed the message and a second message sent by Hasan. Concerned by the implications of the sender possibly being in the U.S. military, the JTTF sent a "routine discretionary action lead" to the International Terrorism Operations Section 1 at FBI Headquarters and the JTTF in the Washington, DC, Field Office on January 7, 2009. It attached both messages that Hasan sent to al-Awlaqi and noted that al-Awlaqi had not replied. ${ }^{18}$

The FBI supervisory special agent in the Washington Field Office did not assign the lead until about February 25, 2009, a delay the Webster Commission stated was likely due, in part, to the focus at the time on security concerns over President Barack Obama's inauguration. Informal FBI guidelines required work on routine leads to be completed within 90 days. The JTTF officer assigned in Washington waited until the 90th day, May 27, 2009, to read the lead and take action. The agent spent just four hours on the assessment. The Webster Commission judged the delay was "unreasonable" and "may have affected the shape, scope and outcome of [Washington Field Office's] assessment of Hasan, which took place in four hours on that ninetieth day." ${ }^{19}$

With the benefit of hindsight, the assessment at the end of those four hours that Hasan's e-mails were benign and he posed no threat was greatly consequential. According to the Commission, the JTTF officer in the Washington Field Office decided it was not necessary to interview Hasan or follow up with Hasan's superiors after seeing almost uniformly positive reviews in Army evaluation reports. For example, the department chair of psychiatry at Walter Reed wrote that Hasan's research on Islamic beliefs concerning military service during the global war on terrorism "has extraordinary potential to inform national policy and military strategy." ${ }^{20}$ According to the Webster Commission, "Based on what he read, [the Washington Field Office JTTF officer] believed that Hasan's communications with [al-Awlaqi] were relevant to his research on Islam and the military. . . [and] that Hasan was not involved in terrorist activities." ${ }^{21}$

The Washington Field Office assessment frustrated the San Diego JTTF officer charged with the alAwlaqi investigation. One member of the San Diego team e-mailed the Washington JTTF officer on June 12, 2009, to inquire whether Hasan might even be an informant to the Washington Field Office:

The response looks a little slim. i.e. limited probing into this individuals background, no contact $\mathrm{w} /$ command and no interview of Hasan. We were wondering if we were missing something, i.e. we need to read between the lines (Hasan is a friend of [Washington Field Office])? ${ }^{22}$

The Washington Field Office agent e-mailed back stating that he had not contacted Hasan, nor his command, directly, but his Army-sponsored research was in line with the questions he sent al-Awlaqi. Additionally, the agent conveyed that Hasan was not a confidential human source. The agent concluded by asking "If you have additional information regarding HASAN's links to terrorism or request any specific action, please share and we will reassess."23

The San Diego team did not send such information. Despite the fact that they reviewed a trickle of new messages between Hasan and al-Awlaqi after first contacting the Washington Field Office, they never 
associated these messages with Hasan's initial two messages or the lead they sent to Washington. This may have been partly a function of the high number of electronic documents they needed to review in the al-Awlaqi investigation (as many as 70 per day) and partly a function of lack of access to the FBI's Data Warehouse System-Electronic Surveillance Data Management System database, ${ }^{24}$ which stored the AwlaqiHasan e-mails. According to the Webster Commission, one of the San Diego team did not even know about the FBI's database until after the attack, while two others involved in the al-Awlaqi lead in San Diego did not have access to it before the attack..$^{25}$

As a result, after Hasan sent the first two messages, the San Diego team did not flag any further messages to the Washington JTTF. According to the Webster Commission, the Washington Field Office was partly to blame. It found that the delay in Washington following up the lead "pushed Hasan further from the minds" of the San Diego agents. ${ }^{26}$ The Commission also judged that the Washington Field Office "erred in failing to search the [database] after the passage of five months since the initial e-mail from Hasan, if only to determine whether [al-Awlaqi] had replied to Hasan's messages." If they had searched the database, they could have seen additional communications, including al-Awlaqi's two e-mails to Hasan, yet the JTTF officer in Washington responsible for looking into the lead had not even been told about the existence of the database.

According to the Commission, if the Washington Field Office had seen the additional messages, it "could have undermined the assumption that Hasan had contacted [al-Awlaqi] simply to research Islam." The FBI's supervisory special agent who oversaw the handling of the case in Washington later said that, with the benefit of hindsight, the Washington Field Office would have opened a preliminary investigation into Hasan if he had seen all of the additional messages. ${ }^{27}$

In addition, the belief of the Washington Field Office "that the Army encouraged Hasan's research and would approve of his communications with [al-Awlaqi]" may have been different had they had access to files maintained locally by Hasan's command, which were far more critical of his performance. As the Senate report stated, "the FBI and [Department of Defense] together failed to recognize and to link the information that they possessed." If they had, Hasan would likely have been scrutinized more intensively. ${ }^{28}$ In fact, after the media began reporting on Hasan's attack, one of the FBI agents is said to have told his colleague in San Diego: "You know who that is? That's our boy." 29

In sum, the Senate committee and Webster Commission reviewing the circumstances around the Fort Hood shooting uncovered shortcomings in awareness and access to key databases, sharing information, a failure of either San Diego or Washington to take ownership of the lead, and a right hand not knowing what the left hand is doing dynamic within the FBI-JTTF structure. As a result, the FBI did not piece together the full scope of communications between Hasan and al-Awlaqi before the attack.

The Commission concluded that "individuals who handled the Hasan information made mistakes" and that the Washington Field Office "assessment of Hasan was belated, incomplete and rushed primarily because of their workload" and shortcomings in protocols, technology, and training "to navigate the everexpanding flow of electronic information." 30

While a more aggressive and coordinated probe, as well as an interview with Hasan, may have flagged him as a threat, it is not certain it would have prevented an attack. Even if Hasan had been dismissed from the Army, he would presumably have had other opportunities to target soldiers on U.S. soil. E-mails obtained by the FBI after the attack did not reveal any messages in the two weeks prior to the mass shooting suggesting Hasan was about to launch an attack. Moreover, as the Commission noted, "Other than his eighteen communications with Anwar [al-Awlaqi], he had no known contact and no known relationships with criminal elements, agents of foreign powers, or potential terrorists." ${ }^{31}$

Counterterrorism agencies on both sides of the Atlantic have found that it is difficult to intercept individuals who decide to conduct an attack if they fail to inform another individual about their plans. 


\section{The Boston Marathon bombings}

At 2:49 PM on April 15, 2013, two brothers-Tamerlan and Dzhokhar Tsarnaev-remotely detonated two pressure-cooker bombs they had just placed along the final stretch of the Boston Marathon route. The blasts, which were seconds apart, sent shrapnel across a wide area, killing 3 spectators and wounding 260 people.

Three days later, and just hours after the FBI released closed-circuit television images of the suspects, the Tsarnaev brothers shot dead Sean Collier, a Massachusetts Institute of Technology police officer who was sitting in his police cruiser, in a failed attempt to steal his firearm. They then hijacked a Mercedes sport utility vehicle so they could drive undetected to New York City to launch another attack using their remaining pipe bombs and a pressure-cooker bomb. The driver of the Mercedes, however, escaped during a stop at a gas station and called police. As a result, police located the brothers by tracking the vehicle's global positioning system to the Boston suburb of Watertown in the early hours of April 19.

The Tsarnaev brothers engaged the responding Watertown police officers in a gunfight and lobbed several pipe and pressure cooker bombs in their direction, some of which exploded. In the resulting melee, Dzhokhar Tsarnaev ran over his already wounded brother in an attempt to kill the police officers, contributing to his brother's death. Bleeding from gunshot wounds, Dzhokhar fled in the Mercedes and was arrested later that day hiding in a dry-docked boat in a residential area of Watertown. The owner of the boat discovered him and called 911. Dzhokhar Tsarnaev later told interrogators that he and his brother were planning a subsequent attack in New York City's Times Square. ${ }^{32}$

In 2015, Dzhokhar was convicted of the attacks after a trial in Boston. ${ }^{33}$ No terrorist group claimed responsibility, but the month after the bombings, al-Qaida's affiliate in Yemen-al-Qaida in the Arabian Peninsula—-praised the Tsarnaevs in its Inspire English-language magazine. ${ }^{34}$

\section{Genesis of the plot}

The Tsarnaev brothers entered the United States a decade before they bombed the Boston Marathon. Ethnic Chechens, they were born in Kyrgyzstan, where their father worked before the family moved to the United States. Tamerlan became a U.S. permanent resident in 2006, and authorities were processing his application for citizenship at the time of the attacks. Dzhokhar became a naturalized U.S. citizen in September 2012. At the time of the Boston bombings, Tamerlan was 26 years old, while Dzhokhar was a 19-year-old student at the University of Massachusetts-Dartmouth. ${ }^{35}$

Growing up, Dzhokhar idolized his older brother. Tamerlan had a volatile personality and increasingly turned to Islam as hopes of pursuing a career in boxing faded. Tamerlan became an avid consumer of Islamic content online and conspiracy-related websites and began to grow interested in the conflict in Chechnya. ${ }^{36}$

By 2011, Russian intelligence services had Tamerlan on their radar. In March 2011, the Russian Federal Security Service (FSB) sent the FBI a letter expressing concern that he had become radicalized and might seek to travel to Russia to join extremist groups. ${ }^{37}$ Moscow sent the same warning to the Central Intelligence Agency (CIA) that September. ${ }^{38}$ At some point the same year, Dzhokhar started to read terrorist writings and began posting online messages about the persecution of Muslims. ${ }^{39}$

In September 2011, Tamerlan, who had begun low-level drug dealing, may have participated in a brutal triple homicide in a Boston suburb in an apparent "drugs rip-off." Investigators gathered mounting evidence of his possible role in the killings after the Boston bombings. ${ }^{40}$ One of those murdered had been well known to him. Two of the homicide victims were Jewish. While being questioned about the murders, Ibragim Todashev, an associate of Tamerlan, was shot dead after he attacked an FBI agent during an interrogation a little over a month after the bombings. Todashev acknowledged he and Tamerlan carried out the murders. ${ }^{41}$ 
In January 2012, Tamerlan traveled to Russia, where he stayed with relatives in Makhachkala, the capital of Dagestan, a region that was at the time the center of the simmering jihadi insurgency in the Caucasus. ${ }^{42}$ But there is no evidence that he sought out jihadi groups or that he received terrorist instruction while in Dagestan. ${ }^{43}$

Upon his return to the United States in July 2012, Tamerlan grew a five-inch-long beard, and his radical views appear to have hardened. ${ }^{44} \mathrm{He}$ created a YouTube account, which showed he compiled playlists of jihadi videos, including "The Emergence of the Prophecy: The Black Flags of the Khorasan." The video detailed a prophecy about an army arising out of Afghanistan near the end of days, which has been cited by al-Qaida to justify its actions. At a Boston area mosque Tamerlan attended, he engaged in shouting matches with preachers, one of whom he accused of being a disbeliever. Congregants asked him to leave. ${ }^{45}$

The brothers appear to have started plotting the Boston bombings in late 2012. According to court documents, around Christmas that year, they accessed instructions on "making a bomb out of a pressure cooker filled with explosive powder and shrapnel" contained in al-Qaida in the Arabian Peninsula's Inspire magazine, which had been overseen by al-Awlaqi until his death in a U.S. airstrike in September 2011. ${ }^{46}$

Dzhokhar had nearly the complete set of Inspire magazines on his computer. When they built their bombs, the brothers used "improvised fuses made from Christmas lights and improvised, remote-control detonators fashioned from model car parts" and "filled the bombs with explosive powder emptied from ordinary fireworks, as well as nails, tacks, and BBs to make them more deadly." ${ }^{47}$ Like Hasan, the brothers consumed al-Awlaqi's propaganda. In March 2010, al-Awlaqi declared that jihad against the United States was binding on all Muslims. ${ }^{48}$

In the weeks leading up to the attacks, Dzhokhar created an online identity to spread radical ideas, and he obtained a handgun from a friend. The brothers purchased the materials necessary to make the bombs, with Tamerlan traveling to a fireworks store in New Hampshire in February 2013 to purchase 48 mortars containing low-explosive powder. The brothers "appeared to have crushed and emptied hundreds of individual fireworks containing black powder in order to obtain explosive fuel for the bombs." ${ }^{49}$ Around four weeks before the attacks, the brothers conducted target practice at a firing range in New Hampshire. ${ }^{50}$ Investigators did not establish where the brothers constructed the bombs. ${ }^{51}$

\section{Missed warning signs?}

With the benefit of hindsight, there were four missed opportunities to identify the brothers as serious threats. The first was the failure to make more headway in the investigation into the triple homicide in September 2011 in which Tamerlan (according to Todashev) participated, or even question Tamerlan about an attack that killed one of his close acquaintances. ${ }^{52}$ The second was that no one in the brothers' circle in Boston, including those at the Boston-area mosque who had witnessed Tamerlan's angry outbursts, appears to have ever reported any concerns about the brothers' state of mind to law enforcement. ${ }^{53}$

The third missed opportunity related to the actions of U.S. intelligence, border security, and law enforcement agencies following the Russian warnings. The fourth missed opportunity was that the brothers' extremist social media activities were not discovered until after the attacks, despite the fact that Tamerlan came onto the radar screen of counterterrorism agencies. The next sections examine the third and fourth potential missed opportunities in greater detail.

\section{The probe into Tamerlan Tsarnaev}

According to a 2014 Inspectors General report, the FBI legal attaché in Moscow received a memorandum in Russian from the FSB in March 2011 about Tamerlan and his mother. ${ }^{54}$ The memorandum alleged both were adherents of radical Islamist ideologies and that Tamerlan was preparing to travel to Russia to join 


\section{Paul Cruickshank}

unspecified "bandit underground groups" in Dagestan and Chechnya. The Russians requested the FBI give the FSB specific information about the pair, including possible future travel by Tamerlan to Russia. ${ }^{55}$

As a result of the Russian warning, the Boston JTTF conducted an assessment of Tamerlan, which involved an agent performing database searches, "drive-bys" of his residence, an on-site visit to his former college, and interviews with Tamerlan and his parents. ${ }^{56}$ In his interview, Tamerlan said he did not view extremist websites. ${ }^{57}$ In June 2011, the FBI closed its assessment, "finding no link or nexus" between Tamerlan and terrorism. ${ }^{58}$ Two months later, U.S. officials sent a letter to the FSB informing them that no derogatory information had been found about Tamerlan and requesting more information. ${ }^{59}$ There is no evidence the FSB ever responded before the Marathon bombings. ${ }^{60}$

The Inspectors General report noted that the JTTF agent in Boston conducting the assessment did not contact local law enforcement; visit the mosque Tamerlan attended; or interview Tamerlan's wife, his exgirlfriend whom he had been arrested for assaulting in 2009, or his friends and associates. ${ }^{61}$ The agent later said he did not find sufficient derogatory information to justify these additional steps. After the attacks, Tamerlan's former girlfriend revealed he had started shifting toward radical Islamist beliefs between 2006 and 2009, but it is not clear whether she would have revealed this before the bombings. ${ }^{62}$

In September 2011, the FSB provided the CIA with the same information that it had provided to the FBI. This resulted in the National Counterterrorism Center establishing a record for him in the Terrorism Identities Datamart Environment database, the U.S. government's central repository of the names known or "appropriately suspected" of involvement in international terrorism, which that year had over a half million entries. ${ }^{63}$

In the run-up to Tamerlan's travel to Russia in January 2012, the Boston JTTF agent was most likely informed of the upcoming travel by the Customs and Border Protection officer who received notification of Tamerlan's impending travel, according to the post-attack review by the Inspectors General. The Boston agent most likely then told the Customs officer the lead was closed and there was no interest in Tamerlan's travel. ${ }^{64}$

When Tamerlan departed from New York's John F. Kennedy International Airport on his trip to Russia, Customs did not review his record nor conduct an outbound inspection because he was judged a lower priority relative to other passengers of potential concern. When he returned to the United States in July 2012, Tamerlan was not identified as a potential subject of interest and therefore not directed to secondary inspection. While there had initially been instructions for Tamerlan to receive a secondary inspection when he re-entered the United States, by the time he flew back, this was apparently no longer deemed necessary. ${ }^{65}$

Given the FBI had shut down its probe into Tamerlan by this stage, it is impossible to know whether further questioning would have raised any additional red flags. Nevertheless, the Boston JTTF agent, if he was indeed alerted about Tamerlan's travel to Russia, never brought this to the attention of his supervisor. During the review by the Inspectors General, this supervisor stated that had he been informed of the travel, he would likely have re-opened the assessment. The JTTF agent, however, stated that he did not recall having a practice of notifying his supervisor of travel notifications in closed assessments. The head of the Boston JTTF said that if someone had "pinged" the JTTF agent about Tamerlan's travel, it would have "changed everything." The FBI legal attaché in Moscow between May 2011 and October 2012 stated he was never made aware of the travel, that it was "huge," and that normally this information would have led the FBI to reopen the assessment and seek additional information from the FSB. ${ }^{66}$ The Inspectors General report concluded that Tamerlan's travel to Russia was "significant in view of the FSB lead information and warranted further investigative action." ${ }^{67}$

Questions were raised in the aftermath of the attack over whether officials missed warning signs during Tamerlan's naturalization application process after he applied for U.S. citizenship in August 2012. Yet the Inspectors General report found that while Tamerlan's naturalization application was transferred for additional review because he had previously been flagged, the Boston JTTF agent informed the immigration 
services officer that "there is no national security concern related to [Tamerlan Tsarnaev] and nothing that I know of that should preclude issuance of whatever is being applied for." ${ }^{6}$

Another question mark concerns information sharing. According to then-Boston Police Commissioner Edward Davis, at no point before, during, or after the 2011 Boston JTTF assessment was the Boston Police Department alerted to the potential threat posed by Tamerlan Tsarnaev, but it is unclear whether this would have made any difference. ${ }^{69}$

\section{Extremist social media activities}

Despite the assessment that was opened into Tamerlan, U.S. counterterrorism agencies did not flag, as far as has been publicly stated, any of his online jihadi activity until after the attacks. In the two months leading up to the bombings, Tamerlan's own name was set as the "display name" on a YouTube account he maintained featuring jihadi videos, which likely would have been found through open-source searches had the probe into him still been open. He had previously maintained the account under a different "display name." ${ }^{\prime 70}$

Additional information on Tamerlan's online jihadi activities and download history that were subsequently obtained from analysis of a computer Tamerlan used would only have been discovered before the attacks if the FBI had opened a full investigation into him, according to the Inspectors General report. It was only after the attacks that authorities pieced together what type of websites the brothers had accessed online. $^{71}$

\section{The San Bernardino attack}

Shortly after 9 AM on December 2, 2015, Syed Rizwan Farook, a 28-year-old food safety inspector for the San Bernardino County Division of Environmental Health Services, arrived at a training session and holiday party for him and his coworkers in a conference room inside the Inland Regional Center in San Bernardino, California. While there, he placed a bag on a table before leaving the venue in a black sport utility vehicle at 10:37 AM. $^{72}$

Twenty minutes later, he returned with his wife, Tashfeen Malik. The two were dressed in dark, military-style clothing and opened fire on those in and near the conference room with powerful semi-automatic AR-15-style rifles, killing 14 and injuring 22. By the time police arrived minutes later, the couple had fled the scene. At 11:14 AM, Malik posted a pledge of allegiance on behalf of her and her husband to then-Islamic State leader Abu Bakr al-Baghdadi on Facebook. ${ }^{73}$

During their sweep of the building, authorities discovered a secondary explosive device Farook had placed in the bag to target arriving police officers. The bag contained three galvanized steel pipe bombs containing smokeless powder and a Christmas light initiator, which was wired to a remote-control toy car to create a radio-controlled improvised explosive device. The device was "switched on" and had close similarities to the explosive devices built by the Boston Marathon bombers. ${ }^{74}$

Shortly after 3 PM, investigators located the black sport utility vehicle which the couple had been driving around the area, and a high-speed pursuit and firefight ensued. Police killed both Farook and Malik. The two had fired over 80 rounds at officers. Afterwards, police recovered a Smith and Wesson AR-15-style rifle, an Oracle AR-15-style rifle, and two semi-automatic handguns near the vehicle. In the car, they found what they believed was the trigger apparatus for the secondary device left behind at the Inland Regional Center. ${ }^{75}$

The couple had been circling within seven miles of the attack site. Investigators believe they had been trying to remotely set off the explosive device they left behind. Three days after the attack, the Islamic State called the attackers "soldiers of the caliphate," a description it has used for those carrying out terrorist attacks in its name. No evidence has emerged the couple received any direction from terrorists overseas. ${ }^{76}$ 


\section{Genesis of the plot}

It is not exactly clear when Farook, the Chicago-born son of Pakistani immigrants to the United States, first became radicalized. An American citizen, Farook reportedly had a difficult childhood growing up in Riverside near San Bernardino, California. After attending Riverside City College and California State University San Bernardino, he held a series of jobs for San Bernardino County, including at its Department of Public Health between 2010 and the attack in December 2015. ${ }^{77}$

By 2005, Farook seems to have had some interest in the Tablighi Jamaat movement, a group with hundreds of thousands of members worldwide. Although largely apolitical and non-violent, its followers have a reputation for zealousness, which can make them vulnerable to radical influences. Like Nidal Hasan and the Tsarnaev brothers, Farook became increasingly influenced by the sermons and propaganda of alAwlaqi. Farook imparted this radical ideology to Enrique Marquez, a friend he introduced to Islam. In 2011, Marquez read Inspire magazine and other extremist content at Farook's residence. That year Farook expressed an interest in joining al-Qaida in the Arabian Peninsula in Yemen, Marquez revealed to FBI agents after the attack. ${ }^{78}$

Farook's terrorist plotting began in 2011 when he and Marquez started discussing becoming martyrs. ${ }^{79}$ According to what Marquez told the FBI after the San Bernardino attack, he and Farook discussed using firearms and pipe bombs to attack a library or cafeteria at Riverside City College (where they had both previously been registered as students) and to target traffic moving along a local highway during rush hour, with the intent being in both attacks to "maximize the number of casualties." ${ }^{80}$ They had been inspired by Nidal Hasan's shooting at Fort Hood in Texas two years prior and also studied the mass shooting carried out by Anders Breivik in Norway in 2011. ${ }^{81}$

In the months that followed, Marquez legally bought rifles, including the Smith and Wesson and Oracle rifles found near the black sport utility vehicle after the San Bernardino attack, and smokeless powder, which investigators established matched that inserted in the improvised explosive device Farook left behind at the Inland Regional Center.

In their later-abandoned 2011-2012 plot, Marquez revealed that he and Farook had consulted Inspire magazine for how to construct a bomb. ${ }^{82}$ It was decided Marquez should buy the firearms because "his appearance was Caucasian while Farook looked Middle Eastern.” Farook limited himself to buying ammunition and firearms components for use on the AR-15-style guns. The two took multiple trips to local firing ranges. ${ }^{83}$

Marquez told investigators he ceased plotting with Farook after the FBI made terrorism arrests near where they lived in late 2012. ${ }^{84}$ In February 2017, Marquez pleaded guilty to hatching the 2011-2012 plot and transferring the guns later used in the San Bernardino attack. Prosecutors said there was no evidence Marquez had advance knowledge of the attack. In October 2020, Marquez was sentenced to 20 years in prison..$^{85}$

Farook married Tashfeen Malik in 2014 after meeting online and traveling to see her in Saudi Arabia. During their online courtship in 2013, they made clear in direct private messages their shared commitment to jihadism and martyrdom. ${ }^{86}$ There is still much that is not clear about Malik's descent into extremism, but investigators have established that she was radicalized before she came into contact with Farook.

Born in Pakistan, Malik grew up in Saudi Arabia, where she was raised in a conservative interpretation of Islam before returning to Pakistan to study pharmacology at a university in Multan. While she was in the city, she enrolled in a Quran course run by an institute with conservative Islamic values. Malik entered the United States in July 2014 on a K-1 fiancé visa with a Pakistani passport, married Farook one month later, and was granted a conditional green card in July $2015 .{ }^{87}$

It is still not clear what triggered Farook and Malik to carry out an attack, but the Islamic State's calls for attacks in the United States presumably influenced them. In September 2014, the senior Islamic State leader Abu Muhammad al-Adnani called for attacks on U.S. soil. Investigators believe the married couple started planning an attack by late 2014, visiting gun ranges in the year leading up to their violent assault. 
Investigators have found no indication of any direct contact between the couple and any terrorist organization. Although the couple pledged allegiance to Islamic State leader Abu Bakr al-Baghdadi via Facebook shortly after the attack, they appear not to have had a deep knowledge of the terrorist organization. They reportedly had to search the internet earlier in the day of the attack for the name of al-Baghdadi. ${ }^{88}$

Six months before the attack, Malik gave birth to a baby girl. Three weeks before the attack, Farook stopped attending a local mosque. It is not clear what tipped the couple to turn their plotting into action. Just two weeks before the attack, Farook had a heated exchange about Islam at work with a co-worker. It remains unclear why the couple targeted Farook's work function in the conference room at the Inland Regional Center. According to the Los Angeles Times,

San Bernardino Police Lt. Mike Madden noted that in 2014, Farook attended another work event in that room, which was decorated for Christmas. Malik later stated on an online account something to the effect that she felt Muslims should not have to attend Christian events, Madden said. Madden added that she did not specifically mention the event in her posting and that it's far from clear that it played any role in the attack. ${ }^{89}$

\section{Missed warning signs?}

Unlike Nidal Hasan and Tamerlan Tsarnaev, neither Farook nor Malik came onto the FBI's radar screen. They also did not appear on any watchlists. ${ }^{90}$ One possible missed opportunity to detect a threat was Farook's reported digital contact with people suspected of links to overseas terrorist groups, but no suggestion has been made that these were known to U.S. intelligence before the attacks. ${ }^{91} \mathrm{~A}$ second potential missed opportunity was that U.S. agencies did not pick up private radical messages between the couple that were sent during their online courtship, nor their downloading of extremist materials. ${ }^{92}$

A third possible missed opportunity to uncover a threat was the fact that no signs of radicalization were detected during Malik's visa and green card applications. A fourth possible missed opportunity was that no one came forward to alert the government over concerns about the couple's radical views. A fifth potential missed opportunity was Farook's possible ties to the subjects of earlier terrorism arrests in the area, but any ties appear to have been only loose. This section now looks into each of these five potential missed opportunities.

\section{Communication with suspected terrorists}

It was reported that Farook had communicated with extremists inside and outside the United States a few years before the attack. He reportedly had contact with five people whom the FBI had investigated for possible terrorist activities, including "some kind of digital contact" with one associated with the Somali al-Qaida affiliate al-Shabaab and another associated with the Syrian al-Qaeda affiliate Jabhat al-Nusra, but in the aftermath of the attack, no evidence emerged that he had communicated with anyone of "significant investigative concern. ${ }^{93}$

It is not clear when U.S. agencies collected this information, but no suggestion has been made that it was flagged before the attack. U.S. officials have not publicly confirmed the communications. In a press conference two weeks after the attack, and after these media accounts were published, FBI Director James Comey said investigators had not seen indication of direct contact with foreign terrorist organizations. ${ }^{94}$

\section{Radical private messages}

Two weeks after the attack, Comey stated that "so far we've seen no indication that either of these two killers came across our screen, tripped any trip wires, anything that either brought them to our attention or should have brought them to our attention." 95 Thus, before the attack, U.S. agencies were not aware that 


\section{Paul Cruickshank}

Farook or Malik were downloading extremist content. They did not intercept or flag any of the private messages expressing support for jihad exchanged between Farook and his wife during their online courtship. These were only discovered after the attack once the FBI opened a full investigation. ${ }^{96}$

Although this was a possible missed opportunity to detect a threat, it is hard to see how U.S. security agencies could have previously known about the private messages exchanged by Farook and his wife or about their download history without other evidence leading to the opening of an investigation. It should be noted that even in the days after the FBI had opened an expansive investigation of the attackers, investigators did not uncover public social media messages in support of jihad by Farook or his wife. ${ }^{97}$

\section{The visa and immigration vetting of Malik}

It has been suggested that U.S. security agencies should have picked up signs Malik was radicalized during the vetting process for her visa and green card, but given neither she nor her husband publicly posted radical content online, this would have been difficult for the vetting agencies to discover. A senior State Department official told CNN that when a U.S. Consular official interviewed Malik for her fiancé visa in May 2014, she was not asked about jihadi leanings because no red flags were found in the application. Following the interview, Malik passed two other security database checks before her visa was granted. ${ }^{98}$

\section{No tips from the community}

U.S. counterterrorism agencies appear never to have received any tips the couple might pose a threat. As far as is known, Farook's circle of friends and family in California did not report any concerns to law enforcement. Some of his family members later said he was outspoken in his fundamentalist views, but said they had no idea Farook planned violence..$^{99}$ Farook was highly secretive, however, and it appears that only his wife was aware of his plan to carry out the San Bernardino attack. ${ }^{100}$

Malik wore the niqab (full veil) - a sign of very conservative but not violent extremist views - and mostly stayed at home once she arrived in California. In two private Facebook messages she sent in Urdu in 2012 and 2014 to a small group of friends in Pakistan, which were uncovered by investigators after the attack, she made clear her support for jihad and her hope to join the fight one day. ${ }^{101}$ Her family in Pakistan had grown concerned when she started posting radical messages via her Facebook page after she arrived in the United States, a family member there stated in an interview without specifying whether these were public or private messages. ${ }^{102}$ Yet, as far as is known, they did not alert authorities.

Although the couple assembled an arsenal of weapons and built bombs in the garage of their home, there is no evidence that neighbors or others were aware. ${ }^{103}$ There was subsequently a false claim that several witnesses saw explosives at the home of the attackers but did not alert law enforcement. ${ }^{104}$

\section{Loose ties to a jihadi terror travel cell}

One question is whether the loose connections that appear to have existed between Farook and a jihadi travel cell could or should have led to some scrutiny of Farook before the attack. The limited information that has been made public about these connections, and what was known when, make it a difficult question to answer, but no evidence has come to light that this was a dropped ball.

Investigators established after the San Bernardino attack that around the 2011-2012 period when Farook and his friend Enrique Marquez were plotting attacks, "Marquez had ties to a group of [California jihadis] who were arrested in 2012 when they attempted to travel to Afghanistan to join al-Qai'da." The criminal complaint in the Marquez case noted that one of those arrested was Ralph Deleon, a U.S. permanent resident from the Philippines who lived near the Riverside/San Bernardino area. ${ }^{105}$ The court documents further stated that "after the arrests of the California jihadists in 2012, Marquez distanced himself from Farook." 106 
In November 2012, authorities announced the arrest of four men, including Deleon-who were living or had resided in and around Riverside and who were inspired by the doctrines of Anwar al-Awlaqi-on suspicion of plotting to travel overseas to Afghanistan, join al-Qaida, and kill Americans. The ringleader of the group-Sohiel Omar Kabir, an Afghan-born American citizen-was arrested in Afghanistan after traveling there and encouraging others in the group to join him. Kabir and Deleon were convicted in 2014 for their roles in the jihadi terrorism travel plot. ${ }^{107}$

U.S. authorities have not yet provided clarity on the nature of the connection between Marquez and the four-man jihadi travel cell. According to the FBI, their investigations did not uncover any "direct ties" between Marquez and the four men. Officials told CNN that the San Bernardino attacker Farook was in Kabir's social circle but was not among those investigated at the time of the probe into Kabir's jihadi travel plot. ${ }^{108}$

\section{The Orlando nightclub attack}

Just after 2 AM on June 12, 2016, Omar Mateen, a 29-year-old American of Afghan descent, entered the Pulse gay nightclub in Orlando and started shooting, firing more than 200 rounds from a semi-automatic rifle and handgun in the initial minutes of his attack. Clubgoers fled for the exits and places to hide. ${ }^{109}$

An Orlando Police Department detective happened to be working an "off-duty detail" at the nightclub. He engaged Mateen almost immediately after the start of the attack and called for backup. At 2:08 AM, police first responders entered the club and drove Mateen to the rear of the venue, where he barricaded himself in a bathroom where some of those in the club had gone to hide.

A three-hour hostage standoff ensued, during which time Mateen called 911 to say he was responsible for the attack and to announce he was pledging allegiance to Islamic State leader Abu Bakr al-Baghdadi. In follow-up calls with negotiators, he also claimed falsely to have a suicide vest and to have placed bombs in vehicles outside the club. ${ }^{110}$

He also explained the motive for the attack:

You have to tell America to stop bombing Syria and Iraq. They are killing a lot of innocent people. ... What's going on is that I feel the pain of the people getting killed in Syria and Iraq and all over the Muslim Ummah [world]. . . The U.S. is collaborating with Russia and they are killing innocent women and children, okay. . . . My homeboy Tamerlan Tsarnaev ${ }^{111}$ did his thing on the Boston Marathon, my homeboy Moner Abu-Salha did his thing, okay, so now it's my turn, okay? ${ }^{112}$

In a follow-up call, Mateen stated that what triggered his attack was "the airstrike that killed Abu Wahib a few weeks ago." 113

After police learned that Mateen was threatening to place bomb vests on hostages, they breached the wall of the club just after 5 AM. As police prepared to move in, Mateen came out of the bathroom and engaged police in a firefight. Mateen was shot dead. His shooting rampage killed 49 people and injured 53 in what at the time was the deadliest terrorist attack on U.S. soil since 9/11.

The Islamic State claimed that Mateen was "one of the soldiers of the caliphate in America." 114 On May 21, 2016, one of its leading figures, Abu Muhammad al-Adnani, had called for attacks in the West during the Muslim holy month of Ramadan. Mateen's attack occurred almost a week after the start of Ramadan. No evidence has emerged that Mateen was in contact with the group. ${ }^{115}$

\section{Genesis of the plot}

Omar Mateen was a Queens, New York-born son of Afghan immigrants who grew up in Florida. His family was comfortably middle class, but like San Bernardino shooter Farook, Mateen had a troubled 


\section{Paul Cruickshank}

childhood, in his case exhibiting behavioral problems at school and often getting into fights. He was suspended from one school after $9 / 11$ for five days, because he reacted positively to the terrorist attacks. ${ }^{116}$

After graduating from a local community college, he was employed at the Florida Department of Corrections from which he was fired for making an off-color remark during training about bringing a gun "to school." ${ }^{117}$ He then took a job as a private security guard for security firm G4S, which employed him from 2007 onwards. Mateen obtained a firearms license in 2011, carried a gun as part of his duties, and would also obtain a concealed weapons permit. ${ }^{118}$

Mateen married his first wife in 2009 after meeting her online. She referred to him as bipolar. "He was not a stable person," she later said. "He beat me. He would just come home and start beating me up because the laundry wasn't finished or something like that." 119 When asked how he could have been capable of carrying out the attack, she said, "Emotional instability. Sickness. He was mentally unstable and mentally illthat's the only explanation that I could give. And he was obviously disturbed, deeply, and traumatized." 120

They separated after four months and divorced in 2011. That same year Mateen met his second wife, Palestinian-American Noor Salman, online. She would later be acquitted of charges of aiding and abetting the commission of a terrorist act and obstructing justice. In 2011 and 2012, Mateen traveled, like many Muslims from all around the world, to Saudi Arabia for the umrah pilgrimage. ${ }^{121}$

In 2013, while working for G4S at the St. Lucie County Courthouse, Mateen made inflammatory remarks to co-workers, which prompted the county sheriff's office to alert the FBI. Mateen made the bizarre and contradictory claim he had family connections to the Sunni terrorist group al-Qaida but was also a member of the Shia terrorist group Hezbollah, as well as telling his co-workers he hoped that the FBI would raid his family's home so that he could martyr himself. ${ }^{122}$

The FBI opened a preliminary investigation in May 2013 and placed Mateen in its Terrorist Screening Database (also known as the Terrorist Watchlist), ${ }^{123}$ but they were ultimately "unable to verify the substance of his comments." As a result, after 10 months, the FBI closed its investigation and removed him from the database in March 2014. ${ }^{124}$

A few months later, during the summer of 2014, the FBI again looked into Mateen after a man who prayed at the same mosque as he, Moner Abu-Salha, a recruit to al-Qaida's affiliate in Syria, became the first American to carry out a suicide bombing in the country. In the end, the FBI concluded that Mateen only knew the bomber casually. As already noted, Mateen in a call with negotiators during his attack described Abu-Salha as his "homeboy."125

Mohammed Malik, a Muslim acquaintance of Mateen, wrote in the Washington Post that after a posthumous video emerged in the summer of 2014 making clear Abu-Salha had been radicalized by al-Awlaqi's lectures, Mateen had told Malik that he also watched videos of al-Awlaqi and found them very powerful. Malik stated that while he did not think it likely at the time that Mateen would carry out any acts of violence, he informed the FBI that Mateen had been watching tapes of al-Awlaqi. A federal law enforcement officer confirmed Malik's cooperation to the newspaper. ${ }^{126}$

It became clear to investigators after the attack that Mateen had self-radicalized through the internet. Analysis of Mateen's electronic devices after the attack showed searches for jihadi propaganda, including videos of al-Awlaqi, as well as Islamic State beheading videos. Individuals who encountered him at the guard booth at PGA Village, the gated residential complex where he worked from 2014, recalled bizarre, aggressive behavior. ${ }^{127}$

It is not clear exactly when Mateen first began plotting an attack. On April 26, 2016, Mateen brought his wife to Disney World in Orlando. Investigators believed Mateen may have gone there to case it as a potential target. ${ }^{128}$ On May 9, 2016, the Pentagon announced that senior Islamic State leader Abu Wahib had been killed the previous week in an airstrike. The details appear to match the "Abu Wahib" whose death Mateen told police he sought to avenge. As noted by one analyst, since Abu Wahib did not have a big media profile in the West, only an "avid consumer" of Islamic State propaganda would likely have mentioned him. ${ }^{129}$ 
During their unsuccessful prosecution of Mateen's wife, prosecutors stated that Mateen intended to attack Disney World's shopping and entertainment complex by hiding a gun in a stroller but was spooked by the police presence and instead ultimately attacked the Pulse nightclub. Video footage from the Disney Springs complex that captured Mateen in the hours before the Pulse attack showed him looking behind at nearby police officers, forcing him, according to prosecutors, to choose a new target. ${ }^{130}$

Questions have been raised over whether Mateen targeted the Pulse venue in part because of homophobia or struggles with his own sexuality. ${ }^{131}$ Several clubgoers told reporters Mateen had been a regular at the Pulse nightclub and several men claimed sexual relations with him or sightings of him at gay bars, but the FBI has not independently corroborated that he was gay. ${ }^{132}$

Evidence emerged during the trial of Mateen's wife that points against the attack on the Pulse nightclub being premeditated. According to court documents, after leaving Disney Springs on the night of the attack, Mateen drove to another Walt Disney site before conducting a Google search for "downtown Orlando nightclubs.” He first headed to a different club after getting Google map directions for it, then did another Google search for clubs and got directions for Pulse. ${ }^{133}$

Around a week before the attack, Mateen bought the Sig Sauer assault-style rifle and a Glock 9-mm semiautomatic pistol he would use in the attack. He made the purchases at a licensed gun store in Florida. Mateen passed a background check and abided by the state's three-day waiting period in relation to the handgun. ${ }^{134}$

\section{Missed warning signs?}

In retrospect, given Mateen was twice looked into by the FBI, ${ }^{135}$ there were significant warning signs he could pose a threat. Thus far, no comprehensive official report has been released about the attack, making it difficult to identify in detail what different steps could have been taken, but several observations can be made.

\section{The preliminary investigation by the FBI}

The FBI launched a preliminary investigation into Mateen in 2013 after his incendiary remarks at the St. Lucie County Courthouse were flagged. According to Comey, this "involved introducing confidential sources to him, recording conversations with him, following him, reviewing transactional records from his communications, and searching all government holdings for any possible connections, any possible derogatory information. We then interviewed him twice." Because the preliminary investigation was never escalated to a full investigation, the FBI was not permitted to use its most aggressive tools (such as applying for Foreign Intelligence Surveillance Act or Title III warrants to read e-mails and listen to calls). ${ }^{136}$

The FBI sought help from Saudi intelligence with regard to his trips to Saudi Arabia but found no "derogatory" information. During the interviews with FBI agents, Mateen claimed he had made the remarks in anger because he thought his co-workers were discriminating against him and teasing him because he was Muslim. ${ }^{137}$

What seems clear is that Mateen received significantly more scrutiny from the FBI and was the subject of more invasive investigative methods than either Nidal Hasan or Tamerlan Tsarnaev. Although Mateen's social media accounts were not reviewed in the 2013 probe, the Los Angeles Times reported that more intensive monitoring of Mateen's social media accounts "wouldn't have changed the outcome. The postshooting review determined his social media accounts contained no ties to terrorist groups. He did not post radical statements until the night of the shooting, and then just to a group of friends, not the public."138

Under FBI guidelines at the time for the type of probe that was launched, monitoring a suspect's social media $24 / 7$ was not permitted, and authorities generally had to close preliminary investigations within six months if there was no evidence of a crime. The extension of the preliminary investigation to 10 months 


\section{Paul Cruickshank}

would have required sign-off from a special agent in charge and suggested the FBI believed there were more leads to track down at the end of the six-month period. ${ }^{139}$

There has yet to be a full accounting of why the FBI closed its investigation and why Mateen was removed from the Terrorist Watchlist, which resulted in his firearms purchases in the lead-up to the attack not being flagged. If his firearms purchases had been sent to authorities, it might have convinced the FBI to re-open its investigation of Mateen. ${ }^{140}$ Yet it is far from clear whether such a notification would have actually led to a reopening of the probe.

In another potential missed opportunity to stop the attack, one firearms store owner told reporters Mateen asked about high-end body armor and ammunition in bulk in May 2016. An employee grew suspicious, and the store alerted the local FBI office in West Palm Beach, but was not able to tell authorities the name of the prospective buyer because no sale had been made. Furthermore, the store only had grainy surveillance footage. ${ }^{141}$

\section{The tip from the community}

With the benefit of hindsight, one potential missed opportunity was the FBI not more extensively focusing on Mateen in the summer of 2014 after learning from a Muslim acquaintance that Mateen found alAwlaqi's videos "very powerful." Mateen reportedly denied having watched the videos when interviewed by the FBI that July. ${ }^{142}$ "We're going to look hard at our own work to see whether there is something we should have done differently," Comey stated after the attack. "So far, the honest answer is, I don't think so. I don't see anything, in reviewing our work, that our agents should have done differently." 143

\section{Conclusion}

In three out of the four high-casualty terrorist attacks on U.S. soil since 9/11, U.S. counterterrorism agencies had the attackers or one of the attackers on their radar prior to plot execution. In the case of the Fort Hood shooting and Boston Marathon bombings, certain investigators involved in the assessments should, with the benefit of hindsight, have more aggressively investigated leads.

Almost a year before the Fort Hood shooting, the FBI flagged Hasan after agents in San Diego learned he had been communicating with al-Awlaqi, but the Washington Field Office only followed up on the lead in May 2009. In the four hours a JTTF official spent reviewing Hasan's military records and other information, the official decided there was no need to interview or further investigate him. Although military personnel saw signs of Hasan's radicalization, he was never flagged for investigation, nor did the FBI learn about these concerns.

Despite opening an assessment into Boston Marathon bomber Tamerlan Tsarnaev two years before the attack after Russia's warning, the FBI closed the case after a three-month probe, which included an interview with Tamerlan. The Inspectors General review after the attack identified a key possible missed opportunity to prevent it: assuming that he himself was alerted, the JTTF agent handling the case in Boston did not tell his superiors or ask for the assessment to be reopened after Tamerlan traveled to Russia in January 2012. ${ }^{144}$

Authorities did not consider the San Bernardino shooters threats. There have not yet been official reviews or Congressional reports published about how their plotting evaded authorities, so it is not possible to identify any clear missed opportunities that would have prevented the attack. Yet officials after the attack told the media there were communications between Farook and suspected extremists in the United States and overseas. There has been no suggestion these were known to U.S. intelligence agencies before the attacks.

In the case of the Orlando nightclub attack, the FBI conducted a preliminary investigation into Mateen before the attack but terminated its inquiries and removed him from a terrorism watchlist. Why the FBI 
stopped looking into Mateen is not yet fully understood, but one key question is how the FBI evaluated the claim by an acquaintance of Mateen that Mateen was a fan of al-Awlaqi's videos.

U.S. authorities may have had opportunities to prevent some of the attacks if they had become aware of the attackers' private online communications (for example, the courtship messages of the San Bernardino attackers) or radical social media activity (for example, Tamerlan Tsarnaev's YouTube account) beforehand. Yet U.S. counterterrorism agencies cannot target the private messages of U.S. persons without a warrant, and despite increasing emphasis placed on monitoring "publicly available information," U.S. intelligence agencies do not and never will have the manpower to review anything but a fraction of the huge number of public social media postings made by inhabitants of the United States on Facebook, Twitter, and elsewhere. ${ }^{145}$

When asked during Congressional testimony in 2015 about the use of automated tools to flag concerning public jihadi extremist content, Comey stated "there are tools but they are limited in a way you would want them to be. The United States government, unlike some other governments in the world, does not monitor [the] internet." ${ }^{146}$ It should also be pointed out that if intercepting terrorist communications was hard for U.S. intelligence agencies in 2009, it has grown much harder in an age when encrypted messaging apps are so widely available.

From 2009, there was an uptick in the number of Islamist terrorist plots in the United States compared to previous years, partly because of the success of terrorists like al-Awlaqi in using the internet and social media to inspire extremists to attack inside the United States. ${ }^{147}$ The emergence of the Islamic State significantly worsened the threat outlook between 2013 and 2017, as there were more than 30 Islamic Statelinked attack plots in the United States. ${ }^{148}$ The defeat of the Islamic State as a territorial entity in 2019 did not end the jihadi threat to the United States.

The loss of 80 lives in four high-casualty attacks is tragic, and cumulatively there have been over a dozen more fatalities since 9/11 in other attacks by Islamist extremists, including the 2017 West Side Highway attack in New York City and the 2019 shooting at Naval Air Station Pensacola in Florida. Nevertheless, the larger story of U.S. counterterrorism efforts in the years since 9/11 is one of "many lives saved" because of the FBI and other agencies thwarting the large majority of Islamist terrorist plots in the United States since $9 / 11$.

At a time of enduring threats and finite resources, counterterrorism agencies across the Western world have been forced to do a certain amount of triage. Deciding which individuals of concern pose the greatest threat and need to be prioritized for scrutiny will involve making judgment calls. Creating smarter counterterrorism policies from the attacks that slipped through the security net will improve the ability of investigators to get the hard decisions right. As well as human error, reviews have unearthed shortcomings in investigative protocols, the management of leads, training, access to databases, and information sharing.

\section{Notes}

1 For the purpose of this chapter, high-casualty attacks are defined as fatal terrorist attacks that killed 10 or more people or injured dozens.

2 Various types of investigative action are referred to in this article. The attorney general's guidelines in relation to the FBI's domestic investigations "authorize three levels of investigation to address a potential threat to national security: 1) an assessment, which requires an authorized purpose but does not require any particular factual predication; 2) a preliminary investigation, which requires information or an allegation of a possible threat to national security; and 3) a full investigation, which requires an articulable factual basis of a possible threat to national security." Office of the Inspector General, Audit of the Federal Bureau of Investigation's Efforts to Identify Homegrown Violent Extremists Through Counterterrorism Assessments (Washington, DC: U.S. Department of Justice, 2020), 1.

3 Joseph Lieberman and Susan Collins, A Ticking Time Bomb: Counterterrorism Lessons From the U.S. Government's Failure to Prevent the Fort Hood Attack (Washington, DC: U.S. Senate Committee on Homeland Security and Governmental Affairs, 2011).

4 Ibid., 29. 


\section{Paul Cruickshank}

5 Ibid., 31.

6 Webster Commission, Final Report of the William H. Webster Commission on The Federal Bureau of Investigation, Counterterrorism Intelligence, and the Events at Fort Hood, Texas, on November 5, 2009 (2012), 1, 6, 41, 47, 50-52, 58, 68, 82; David Johnston and Scott Shane, "U.S. Knew of Suspect's Tie to Radical Cleric," New York Times, November 9 , 2009, www.nytimes.com/2009/11/10/us/10inquire.html.

7 Webster Commission, Final Report, 50.

8 Ibid., 51.

9 Lieberman and Collins, A Ticking Time Bomb, 20.

10 Ibid., 21; Webster Commission, Final Report, 34 and 50-51.

11 Sudarsan Raghavan, "Cleric Says He Was Confidant to Hasan," Washington Post, November 16, 2009 , www. theledger.com/news/20091116/cleric-says-he-was-confidant-to-hasan.

12 Paula Newton, "Purported al-Awlaki Message Calls for Jihad Against the U.S.," CNN, March 17, 2010, www. cnn.com/2010/WORLD/europe/03/17/al.awlaki.message/index.html; J.M. Berger, "The Enduring Appeal of Al-'Awlaqi's 'Constants on the Path of Jihad',' CTC Sentinel 4, no. 10 (2011): 12-15.

13 “Answers Sought on Fort Hood Suspect's Link to Imam,” National Public Radio, November 10, 2009, www.npr. org/templates/story/story.php?storyId=120266334.

14 Amanda Kim Stairrett, "Prosecutors End Case in Hasan Article 32 Hearing," Killeen Daily Herald, October 22, 2010, https://kdhnews.com/news/prosecutors-end-case-in-hasan-article-32-hearing/article_c2cea5e3-063c-5bb4a978-3cb69bae0501.html; Webster Commission, Final Report, 1.

15 Lieberman and Collins, A Ticking Time Bomb, 27-31; Webster Commission, Final Report, 61.

16 Webster Commission, Final Report, 34-40.

17 Ibid., 41.

18 Ibid., 34-46.

19 Ibid., 46, 53, 57, 77.

20 Ibid., 56-57, 80.

21 Ibid., 56.

22 Ibid., 58-59.

23 Ibid., 59-60.

24 The Webster Commission described the searchable electronic database as at the time being difficult to use and not effective in pinpointing information. Webster Commission, Final Report, 27-29, 36, 46, 82.

25 Ibid., 82.

26 Ibid., 76-77, 82 .

27 Ibid., 80-83.

28 Lieberman and Collins, A Ticking Time Bomb, 8; Webster Commission, Final Report, 80.

29 Lieberman and Collins, A Ticking Time Bomb, 39.

30 Webster Commission, Final Report, 71, 80, 82.

31 Ibid., 6, 68-69.

32 U.S.A. v. Dzhokhar A. Tsarnaev, Jury Trial Day Twenty-Seven, Opening Statement by William D. Weinreb (District of Massachusetts, 2015), 1-28; Committee on Homeland Security, The Road to Boston: Counterterrorism Challenges and Lessons from the Marathon Bombings House Homeland Security Committee Majority Report (Washington, DC: U.S. House of Representatives, 2014), 20-21.

33 "Boston Bomber Dzhokhar Tsarnaev Sentenced to Death," BBC, May 15, 2015, www.bbc.co.uk/news/av/ world-us-canada-32757084.

34 Jake Tapper, “Al Qaeda 'Inspire Magazine' Praises Boston Attack,” CNN, May 30, 2013, https://thelead.blogs.cnn. com/2013/05/30/al-qaeda-inspire-magazine-praises-boston-attack/.

35 Inspectors General, Unclassified Summary of Information Handling and Sharing Prior to the April 15, 2013 Boston Marathon Bombings (Washington, DC: Inspectors General for the Intelligence Community, 2014); Janet Reitman, “Jahar's World," Rolling Stone, July 17, 2013, www.rollingstone.com/culture/culture-news/jahars-world-83856/.

36 Reitman, "Jahar's World."

37 Inspectors General, Unclassified Summary of Information Handling, 1.

38 Ibid.

39 U.S.A. v. Dzhokhar A. Tsarnaev, Jury Trial Day Twenty-Seven, 10-11.

40 Serge F. Kovaleski and Richard A. Oppel, Jr., "In 2011 Murder Inquiry, Hints of Missed Chance to Avert Boston Bombing," New York Times, July 10, 2013, www.nytimes.com/2013/07/11/us/boston-bombing-suspect-is-saidto-be-linked-to-2011-triple-murder-case.html.

41 Ibid.; Committee on Homeland Security, The Road to Boston, 21-22; Ally Jarmanning, "Tamerlan Tsarnaev's Friend Told Police They Participated in Waltham Triple Homicide, New Documents Show," WBUR, November $15,2019$. 


\section{Lessons from four high-casualty attacks}

42 Committee on Homeland Security, The Road to Boston, 13.

43 Ibid., 13-15.

44 Ibid.; Reitman, "Jahar's World."

45 Committee on Homeland Security, The Road to Boston, 15; “Tsarnaev Mosque Outbursts Described," Associated Press, April 22, 2013, www.politico.com/story/2013/04/tamerlan-tsarnaev-mosque-outbursts-described-090474.

46 U.S.A. v. Dzhokhar A. Tsarnaev, Jury Trial Day Twenty-Seven, 12.

47 Ibid., 11-12; U.S.A. v. Dzhokar A. Tsarnaev, Government's Opposition to Defendant's Motion to Suppress Statements (District of Massachusetts, 2014), 3.

48 Paul Cruickshank and Tim Lister, "From the Grave, the Cleric Inspiring a New Generation of Terrorists," CNN, April 24, 2013, www.cnn.com/2013/04/24/us/boston-awlaki-influence/index.html; Margaret Coker, "Cleric Cited by Tsarnaev Lives On-Online," Wall Street Journal, May 5, 2013, www.wsj.com/articles/SB100014241278 87323687604578465023366949366; Newton, "Purported al-Awlaki Message."

49 U.S.A. v. Dzhokhar A. Tsarnaev, Jury Trial Day Twenty-Seven, 11-12; U.S.A v. Dzhokar A. Tsarnaev, Indictment (District of Massachusetts, 2013), 7; U.S.A. v. Dzhokar A. Tsarnaev, Government's Opposition, 3.

50 U.S.A. v. Dzhokar A. Tsarnaev, Indictment, 7.

51 Henry Gass, "Who Actually Built the Boston Marathon Bombs?” Christian Science Monitor, March 26, 2015, www. csmonitor.com/USA/USA-Update/2015/0326/Who-actually-built-the-Boston-Marathon-bombs.

52 Peter Bergen and Jennifer Rowland, "Four Things We Learned About the Boston Bombing," CNN, April 15, 2014, www.cnn.com/2014/04/08/opinion/bergen-boston-bombing-five-things/index.html.

53 Committee on Homeland Security, The Road to Boston, 16 and 35-36.

54 Inspectors General, Unclassified Summary of Information Handling, 7.

55 Ibid., 7-8.

56 Ibid., 8.

57 Eric Levenson, “Boston Bomber Tamerlan Tsarnaev Told FBI He Never Picked a Fight,” CNN, April 11, 2017, www.cnn.com/2017/04/11/us/tamerlan-tsarnaev-fbi-boston-marathon-interview/index.html.

58 Inspectors General, Unclassified Summary of Information Handling, 10.

59 Ibid., 10.

60 Ibid., 11.

61 Ibid., 9.

62 Ibid., 9, 18-19 and 22.

63 Ibid., 11; Committee on Homeland Security, The Road to Boston, 33; "Terrorist Identities Datamart Environment (TIDE)," Director of National Intelligence Fact Sheet, accessed December 22, 2020, www.dni.gov/files/NCTC/documents/features_documents/TIDEfactsheet10FEB2017.pdf.

64 Inspectors General, Unclassified Summary of Information Handling, 12-13.

65 Ibid., 13-14.

66 Ibid., 15-16.

67 Ibid., 21.

68 Ibid., 15-17; Henry Gass, "Boston Bomber's Application for US Citizenship Raises New Questions," Christian Science Monitor, February 29, 2016, www.csmonitor.com/USA/Justice/2016/0229/Boston-bomber-sapplication-for-US-citizenship-raises-new-questions.

69 Committee on Homeland Security, The Road to Boston, 25-26.

70 Inspectors General, Unclassified Summary of Information Handling, 19-20.

71 Ibid., 20.

72 Dan Flynn, "Syed Farook's Food Safety Inspection Reports Show Nothing Unusual," Food Safety News, December 4, 2015, www.foodsafetynews.com/2015/12/syed-farooks-food-safety-inspection-reports-show-nothingunusual/; U.S.A. v. Enrique Marquez, Jr., Criminal Complaint (Central District of California, 2015), 20-22; Megan Christie et al., "Christmas Party May Have Triggered San Bernardino Terror Attack: Police," $A B C$ News, December 1, 2016, https://abcnews.go.com/US/christmas-party-triggered-san-bernardino-terror-attackpolice/story?id=43884973; Frank Straub, Jennifer Zeunik and Ben Gorban, "Lessons Learned From the Police Response to the San Bernardino and Orlando Terrorist Attacks," CTC Sentinel 10, no. 5 (2017): 1-7; Mark Berman, "One Year After the San Bernardino Attack, Police Offer a Possible Motive as Questions Still Linger," Washington Post, December 2, 2016, www.washingtonpost.com/news/post-nation/wp/2016/12/02/ one-year-after-san-bernardino-police-offer-a-possible-motive-as-questions-still-linger/.

73 U.S.A. v. Enrique Marquez, Jr., Criminal Complaint, 20-22; Straub et al., "Lessons Learned”; Michael Martinez, Catherine E. Shoichet, and Pamela Brown, "San Bernardino Shooting: Couple Radicalized Before They Met, FBI Says," CNN, December 9, 2015, www.cnn.com/2015/12/09/us/san-bernardino-shooting/index.html.

74 U.S.A. v. Enrique Marquez, Jr., Criminal Complaint, 21-26; Straub et al., "Lessons Learned."

75 Ibid. 


\section{Paul Cruickshank}

76 Rukmini Callimachi, "Islamic State Says 'Soldiers of Caliphate' Attacked in San Bernardino," New York Times, December 5, 2015, www.nytimes.com/2015/12/06/world/middleeast/islamic-state-san-bernardino-massacre. html; Christie et al., "Christmas Party May Have Triggered San Bernardino Terror Attack: Police”; Al Baker and Marc Santora, "San Bernardino Attackers Discussed Jihad in Private Messages, F.B.I Says," New York Times, December 16, 2015, www.nytimes.com/2015/12/17/us/san-bernardino-attackers-discussed-jihad-in-private-messagesfbi-says.html.

77 Sarah Parvini, Matt Hamilton, and Corina Knoll, "Amid Farook Family Violence, Brothers Were a Study in Contrasts," Los Angeles Times, December 11, 2015, www.latimes.com/local/california/la-me-sb-farook-family20151211-story.html; Saeed Ahmed, "Who Were Syed Rizwan Farook and Tashfeen Malik?" CNN, December 4, 2015, www.cnn.com/2015/12/03/us/syed-farook-tashfeen-malik-mass-shooting-profile/index.html; U.S.A. v. Enrique Marquez, Jr., Criminal Complaint, 8-9; "San Bernardino Shooting: Suspect Graduated from Cal State," Press-Enterprise, December 3, 2015, www.pe.com/2015/12/03/san-bernardino-shooting-suspectgraduated-from-cal-state/; Rebecca Kimtich, "What We Know About San Bernardino Mass Shooting Killers Syed Farook and Tashfeen Malik," San Bernardino Sun, December 3, 2015, www.sbsun.com/2015/12/03/ what-we-know-about-san-bernardino-mass-shooting-killers-syed-farook-and-tashfeen-malik/.

78 U.S.A. v. Enrique Marquez, Jr., Criminal Complaint, 3-8.

79 Verified Complaint For Forfeiture [relating to Syed Farook's Life Insurance coverage by Minnesota Life Insurance Company] (Central District of California, 2016), 3-6.

80 U.S.A. v. Enrique Marquez, Jr., Criminal Complaint, 9-11.

81 Verified Complaint For Forfeiture, 5-6.

82 U.S.A. v. Enrique Marquez, Jr., Criminal Complaint, 4, 12-15, 17-18, 22, 25; Mike McIntire, "Weapons in San Bernardino Shootings Were Legally Obtained," New York Times, December 3, 2015, www.nytimes.com/2015/12/04/ us/weapons-in-san-bernardino-shootings-were-legally-obtained.html.

83 U.S.A. v. Enrique Marquez, Jr., Criminal Complaint, 3-4, 12, 18-19.

84 Ibid., 3-4, 12, 20; Kevin Dolak, "Four California Men Charged in Alleged Terror Plot," ABC News, November 20, 2012, https://abcnews.go.com/US/california-men-charged-alleged-terror-plot/story?id=17766529.

85 U.S. Attorney's Office Central District of California, "Enrique Marquez Jr. Agrees to Plead Guilty to Plotting Violent Attacks and Buying Firearms for Shooter in San Bernardino Terrorist Attack," U.S. Department of Justice, February 14, 2017, www.justice.gov/usao-cdca/pr/enrique-marquez-jr-agrees-plead-guilty-plotting-violent-attacks-and-buying-firearms; Michael Balsamo, "Records: Man to Plead Guilty to Aiding San Bernardino Attack," Associated Press, February 14, 2017, https://apnews.com/44e042ec473640b69c588e688dc98bc0/Records:-Man-to-plead-guiltyto-aiding-San-Bernardino-attack; U.S. Attorney's Office Central District of California, "Inland Empire Man Who Admitted Planning Mass Casualty Attacks and Purchasing Firearms Later Used in 2015 Terrorist Attack in San Bernardino Ordered to Serve 20-Year Federal Prison Sentence," U.S. Department of Justice, October 23, 2020, www.justice. gov/usao-cdca/pr/inland-empire-man-who-admitted-planning-mass-casualty-attacks-and-purchasing-firearms.

86 Baker and Santora, "San Bernardino Attackers"; Eyder Peralta, "San Bernardino Attackers Were Radicalized Before Meeting, FBI Director Says," National Public Radio, December 9, 2015, www.npr.org/sections/thetwoway/2015/12/09/459074323/san-bernardino-attackers-were-radicalized-before-meeting-fbi-director-says.

87 Martinez et al., "San Bernardino Shooting”; Declan Walsh, “Tashfeen Malik Was a 'Saudi Girl' Who Stood Out at a Pakistani University," New York Times, December 6, 2015, www.nytimes.com/2015/12/07/world/asia/in-conservative-pakistani-city-a-saudi-girl-who-stood-out.html; Salman Masood and Declan Walsh, "Tashfeen Malik, San Bernardino Suspect, Attended Conservative Religious School in Pakistan," New York Times, December 7, 2015, www.nytimes.com/2015/12/08/world/asia/tashfeen-malik-attended-conservative-religious-school-in-pakistan. html; Justin Fishel, Benjamin Siegel, and Emily Shapiro, "Inside the Immigration File of San Bernardino Shooter Tashfeen Malik," ABC News, December 22, 2015, https://abcnews.go.com/US/inside-immigration-file-sanbernardino-shooter-tashfeen-malik/story?id=35912170; Julia Preston, "San Bernardino Shooting: From Fiancé Visa to Green Card," New York Times, December 3, 2015, www.nytimes.com/live/san-bernardino-shooting/ from-fiance-visa-to-green-card/.

88 Baker and Santora, "San Bernardino Attackers"; Helen Davidson, "Islamic State's Call to Kill Westerners has Terrorism Experts Divided," Guardian, September 22, 2014, www.theguardian.com/world/2014/sep/23/islamicstates-call-to-kill-westerners-has-terrorism-experts-divided; "San Bernardino Shooters Were Radicalized for 'Quite Some Time': FBI,' CBS News, December 8, 2015, www.nbcnews.com/storyline/san-bernardino-shoot ing/san-bernardino-shooters-had-been-radicalized-quite-some-time-fbi-n475736; Pete Williams and Halimah Abdullah, "FBI: San Bernardino Shooters Radicalized Before They Met," NBC News, December 9, 2015, www. nbcnews.com/storyline/san-bernardino-shooting/fbi-san-bernardino-shooters-radicalized-they-met-n 476971.

89 Joel Achenbach and Sari Horwitz, "What Happens Next to the Baby Orphaned by the San Bernardino Shooters?" Washington Post, December 14, 2015, www.washingtonpost.com/news/post-nation/wp/2015/12/14/ 


\section{Lessons from four high-casualty attacks}

what-happens-next-to-the-baby-orphaned-by-the-san-bernardino-shooters/; Michael R. Blood and Eric Tucker, "Friends: Syed Farook Stopped Going to Mosque Weeks Ago," Associated Press, December 3, 2015, www. santacruzsentinel.com/2015/12/03/friends-syed-farook-stopped-going-to-mosque-weeks-ago/; "Friend of San Bernardino Shooting Victim Recalls Heated Conversation About Islam," CBS Los Angeles, December 3, 2015, https://losangeles.cbslocal.com/2015/12/03/friend-of-san-bernardino-shooting-victim-recalls-heated-conversa tion-about-islam/; Richard Winton, "A Year After the San Bernardino Terror Attack, the FBI Is Still Struggling to Answer Key Questions," Los Angeles Times, December 1, 2016, www.latimes.com/local/lanow/la-me-sanbernardino-terror-probe-20161130-story.html.

90 Missy Ryan, Mark Berman, and Joel Achenbach, "Motive Elusive in Deadly San Bernardino Rampage as FBI Takes Over Probe," Washington Post, December 3, 2015, www.washingtonpost.com/news/post-nation/ $\mathrm{wp} / 2015 / 12 / 03 / \mathrm{fbi}$-takes-over-san-bernardino-investigation-as-authorities-seek-motive-for-attack-thatkilled-14-people/; Eric Tucker, Deb Riechmann and Tami Abdollah, "U.S. Officials Search for Missed Red Flags Ahead of San Bernardino Shooting," Associated Press, December 11, 2015, https://apnews.com/article/ c7c88283fb194dafaa109e7691d82245.

91 "Everything We Know About the San Bernardino Terror Attack Investigation So Far," Los Angeles Times, December 14, 2015, www.latimes.com/local/california/la-me-san-bernardino-shooting-terror-investigation-htmlstory. html.

92 Baker and Santora, "San Bernardino Attackers"; Eric Tucker et al., "U.S. Officials."

93 Los Angeles Times, "Everything We Know About the San Bernardino Terror Attack Investigation So Far"; Jennifer Medina et al., "San Bernardino Suspects Left Trail of Clues, but No Clear Motive," New York Times, December 3, 2015, www.nytimes.com/2015/12/04/us/san-bernardino-shooting.html; Christopher Goffard, "They Met Online, Built a Life in San Bernardino-And Silently Planned a Massacre," Los Angeles Times, December 5, 2015, https://graphics.latimes.com/san-bernardino-syed-farook-tashfeen-malik/.

94 Baker and Santora, "San Bernardino Attackers."

95 James Comey, "FBI Director James Comey Press Briefing at the New York Police Department on December 16, 2015," Washington Post, December 16, 2015, www.youtube.com/watch?v=exi1BuVZEFU.

96 Baker and Santora, "San Bernardino Attackers."

97 Adam Goldman and Mark Berman, "FBI: San Bernardino Attackers Didn’t Show Public Support for Jihad on Social Media," Washington Post, December 16, 2015, www.washingtonpost.com/news/post-nation/wp/2015/12/16/ fbi-san-bernardino-attackers-didnt-show-public-support-for-jihad-on-social-media/.

98 CNN Wire, Eric Spillman, and Chris Wolfe, "No Red Flags Found in Tashfeen Malik's Visa Application, So No Questions Asked About Her Learnings," KTLA5 Los Angeles, December 10, 2015, https://ktla.com/news/ local-news/san-bernardino-shooters-began-plotting-attack-before-their-marriage-fbi-director/ .

99 Winton, "A Year After the San Bernardino Terror Attack."

100 Ibid.; "Ex-Colleague: San Bernardino Killer 'Didn't Want to Be in the U.S.," CBS News, December 7, 2015, www.cbsnews.com/news/san-bernardino-shooting-ex-colleague-syed-rizwan-farook-reveals-new-insight/.

101 Parvini et al., "Amid Farook Family Violence”; Walsh, "Tashfeen Malik Was a 'Saudi Girl”"; Aoun Sahi, David S. Cloud, and Brian Bennett, "Exclusive: Tashfeen Malik was 'Modern Girl' Who Began Posting Extremist Messages on Facebook," Los Angeles Times, December 6, 2015, www.latimes.com/local/lanow/la-me-ln-tashfeen-malikfacebook-extremist-messages-20151205-story.html; Richard A. Serrano, "Tashfeen Malik Messaged Facebook Friends About Her Support for Jihad," Los Angeles Times, December 14, 2015, www.latimes.com/local/lanow/ la-me-ln-malik-facebook-messages-jihad-20151214-story.html.

102 Goffard, "They Met Online."

103 Winton, "A Year After the San Bernardino Terror Attack."

104 Matt Hamilton, "Donald Trump Repeats False Claim that Neighbors Saw 'Bombs All Over' Before San Bernardino Attack," Los Angeles Times, October 9, 2016, www.latimes.com/politics/la-na-pol-trump-debate-sanbernardino-20161009-snap-story.html.

105 Verified Complaint For Forfeiture, 6; U.S.A. v. Enrique Marquez, Jr, Criminal Complaint, 20; Office of Public Affairs, "Two Men Who Provided Material Support to Terrorists and Plotted to Kill American Targets in Afghanistan Receive 25-Year Prison Terms," U.S. Department of Justice, February 23, 2015, www.justice.gov/opa/ $\mathrm{pr}$ /two-men-who-provided-material-support-terrorists-and-plotted-kill-american-targets.

106 Verified Complaint For Forfeiture, 7.

107 Office of Public Affairs, "Two Men Who Provided Material Support to Terrorists"; Dolak, "Four California Men Charged in Alleged Terror Plot"; Steve Gorman, "Four Men Charged in California With Plot to Join al Qaeda," Reuters, November 20, 2012, www.reuters.com/article/us-usa-security-arrests/four-men-charged-in-california-withplot-to-join-al-qaeda-idUSBRE8AJ1JQ20121121; Dan Whitcomb, “Two Convicted in California of Conspiring 


\section{Paul Cruickshank}

to Join al Qaeda,' Reuters, September 26, 2014, https://uk.reuters.com/article/us-usa-security-convictions/ two-convicted-in-california-of-conspiring-to-join-al-qaeda-idUKKCNOHL09320140926.

108 Joseph Serna, "Friend of San Bernardino Shooters Had Ties to 'Jihadists' Planning to Fight with Al Qaeda, Prosecutors Say," Los Angeles Times, June 1, 2016, www.latimes.com/local/lanow/la-me-ln-san-bernardino-marquezconnections-jihadists-20160601-snap-story.html; Evan Perez and Pamela Brown, "San Bernardino Shooting: Farook Tied to Jihadist Recruiter, Officials Say," CNN, December 11, 2015, www.cnn.com/2015/12/10/us/ san-bernardino-shooting/index.html.

109 Straub et al., "Lessons Learned"; Camilla Domonoske, Merrit Kennedy, and Emma Bowman, "Suspect Purchased Guns Legally Ahead of Deadliest Shooting in Modern U.S. History," National Public Radio, June 12, 2016, www. kut.org/2016-06-12/suspect-purchased-guns-legally-ahead-of-deadliest-shooting-in-modern-u-s-history.

110 Straub et al., "Lessons Learned"; Julian Hattem, "Orlando Gunman Claimed Shooting Was Motivated by Death of ISIS Operative," The Hill, September 26, 2016, https://thehill.com/policy/ national-security/297801-orlando-gunman-claimed-shooting-was-motivated-by-death-of-isis.

111 It was reported that Mateen had previously told coworkers he knew the Tsarnaev brothers, but investigators had at that earlier time established the claim was fabricated. Spencer Ackerman, "Orlando Shooter Investigated for False Claim of Ties to Boston Marathon Bombers," Guardian, June 13, 2016, www.theguardian.com/us-news/2016/ jun/13/omar-mateen-fbi-boston-marathon-tsarnaev.

112 Negotiation 1, Transcripts of calls with suspect 6-12-16, City of Orlando Pulse Tragedy Public Records; 16-242039 CNT 1, Suspect Calls Audio Files 6-12-16, City of Orlando Pulse Tragedy Public Records.

113 The official transcript of the call spells the name "Abu Wahid," but in the publicly available audio recording, it sounds to this author's ears like Mateen stated "Abu Wahib." A senior Islamic State leader going by the name "Abu Wahib" was killed in a U.S. airstrike in early May 2016. Negotiation 2, Transcripts of calls with suspect 6-12-16, City of Orlando Pulse Tragedy Public Records; 16-242039 CNT 2, Suspect Calls Audio Files 6-12-16, City of Orlando Pulse Tragedy Public Records; Thomas Gibbons-Neff and Joby Warrick, "Notorious Islamic State Leader Killed in Airstrike, Pentagon Says," Washington Post, May 9, 2016, www.washingtonpost.com/news/ checkpoint/wp/2016/05/09/notorious-islamic-state-leader-killed-in-airstrike-pentagon-says/.

114 "ISIS Claims Responsibility for Orlando Mass Shooting," CBS News, June 13, 2016, www.cbsnews.com/news/ mass-shooting-at-orlando-nightclub-pulse-isis-takes-responsibility/.

115 “Islamic State Calls for Attacks on the West During Ramadan in Audio Message," Reuters, May 21, 2016 , www. reuters.com/article/us-mideast-crisis-islamicstate/islamic-state-calls-for-attacks-on-the-west-during-ramadanin-audio-message-idUSKCNOYCOOG

116 Alan Blinder, Jack Healy, and Richard A. Oppel, Jr., "Omar Mateen: From Early Promise to F.B.I. Surveillance," New York Times, June 12, 2016, www.nytimes.com/2016/06/13/us/omar-mateen-early-signs-of-promisethen-abuse-and-suspected-terrorist-ties.html; Dan Barry et al., " 'Always Agitated. Always Mad': Omar Mateen, According to Those Who Knew Him," New York Times, June 18, 2016, www.nytimes.com/2016/06/19/us/ omar-mateen-gunman-orlando-shooting.html; Mitch Weiss and Russ Bynum, "Records: Orlando Gunman Talked About Violence in 3rd Grade," Associated Press, June 17, 2016, www.seattletimes.com/nation-world/ apnewsbreak-woman-says-nightclub-shooter-stalked-her/.

117 Barry et al., "Always Agitated."

118 Blinder et al., "Omar Mateen"; Eyder Peralta, "What We Know So Far About the Orlando Shooting Suspect," National Public Radio, June 12, 2016, www.npr.org/sections/thetwo-way/2016/06/12/481787369/whatwe-know-so-far-about-the-suspected-orlando-shooter; Adam Goldman, Joby Warrick, and Max Bearak, “'He Was Not a Stable Person': Orlando Shooter Showed Signs of Emotional Trouble," Washington Post, June 12, 2016, www.washingtonpost.com/world/national-security/ex-wife-of-suspected-orlando-shooter-he-beat-me/ 2016/06/12/8a1963b4-30b8-11e6-8ff7-7b6c1998b7a0_story.html.

119 Zachary Fagenson, “Gunman in U.S. Massacre Described as 'Quiet' but Grew Hateful,” Reuters, June 12, 2016, https://br.reuters.com/article/us-florida-shooting-gunman-idUSKCNOYY11B.

120 Gregg Toppo, “Ex-Wife: Orlando Shooter 'Very Short-Tempered,' Violent," USA Today, June 12, 2016, www. usatoday.com/story/news/2016/06/12/ex-wife-orlando-shooter/85808768/.

121 Fagenson, "Gunman in U.S. Massacre Described as 'Quiet'”; Goldman et al., " “He Was Not a Stable Person””; Adam Goldman, "Orlando Gunman's Wife Breaks Silence: 'I Was Unaware,," New York Times, November 1, 2016, www.nytimes.com/2016/11/02/us/politics/orlando-shooting-omar-mateen-noor-salman.html; Patricia Mazzei, "Noor Salman Acquitted in Pulse Nightclub Shooting," New York Times, March 30, 2018 , www. nytimes.com/2018/03/30/us/noor-salman-pulse-trial-verdict.html; "Orlando Shooter Visited Saudi Arabia in 2011, 2012-Saudi Interior Ministry," Reuters, June 13, 2016, www.reuters.com/article/instant-article/ idINKCNOYZ1S8. 


\section{Lessons from four high-casualty attacks}

122 Nancy A. Youssef and Shane Harris, "FBI Tracked Orlando Killer Omar Mateen and Came Up Empty," Daily Beast, June 14, 2016, www.thedailybeast.com/fbi-tracked-orlando-killer-omar-mateen-and-came-up-empty; Mark Mazzetti, Eric Lichtblau, and Alan Blinder, "Omar Mateen, Twice Scrutinized by F.B.I., Shows Threat of Lone Terrorists," New York Times, June 13, 2016, www.nytimes.com/2016/06/14/us/politics/orlando-shoot ing-omar-mateen.html; Del Quentin Wilber, "The FBI Investigated the Orlando Mass Shooter for 10 Months and Found Nothing. Here's Why," Los Angeles Times, July 14, 2016, www.latimes.com/nation/la-na-fbi-investiga tion-mateen-20160712-snap-story.html; Adam Goldman, Matt Zapotosky, and Mark Berman, "FBI Had Closely Scrutinized the Orlando Shooter Before Dropping Investigation,' Washington Post, June 13, 2016, www.washing tonpost.com/world/national-security/fbi-had-closely-scrutinized-the-orlando-shooter-before-dropping-investig ation/2016/06/13/838e9054-3177-11e6-8ff7-7b6c1998b7a0_story.html.

123 Youssef and Harris, "FBI Tracked Orlando Killer"; Ron Johnson letter to Michael Horowitz, July 26, 2016, www.hsgac.senate.gov/media/majority-media/chairman-johnson-seeks-independent-review-of-why-orlandoterrorist-was-taken-off-terror-watchlist.

124 Johnson letter to Horowitz.

125 Barry et al., "Always Agitated"; Wilber, "The FBI Investigated the Orlando Mass Shooter"; Goldman et al., "FBI Had Closely Scrutinized the Orlando Shooter"; Blinder et al., "Omar Mateen”; Michael Edison Hayden and Julia Jacobo, "Gunman's Wife Says She Tried to Talk Him out of Attack, Officials Say," ABC News, June 14, 2016, https://abcnews.go.com/US/gunmans-wife-talk-attack-officials/story?id=39841580; Adam Taylor, "Omar Mateen May Not Have Understood the Difference Between ISIS, al-Qaeda and Hezbollah,” Washington Post, June 13, 2016, www.washingtonpost.com/news/worldviews/wp/2016/06/13/omar-mateen-may-not-have-understoodthe-difference-between-isis-al-qaeda-and-hezbollah/.

126 Mohammed A. Malik, "I Reported Omar Mateen to the FBI. Trump Is Wrong that Muslims Don't Do Our Part," Washington Post, June 20, 2016, www.washingtonpost.com/posteverything/wp/2016/06/20/i-reportedomar-mateen-to-the-fbi-trump-is-wrong-that-muslims-dont-do-our-part/.

127 Ralph Ellis et al., “Orlando Shooting: What Motivated a Killer?” CNN, June 14, 2016, www.cnn. com/2016/06/13/us/orlando-nightclub-shooting/index.html; Barry et al., "Always Agitated”; Joe Capozzi, “Exclusive: Madman at the Gate: A Community's Close Encounters With Omar Mateen,” Palm Beach Post, June 10, 2017, www.palmbeachpost.com/news/madman-the-gate-community-close-encounters-with-omar-mateen/oz96 cgJJvWl6tSbWjBjBeN/.

128 Evan Perez, Shimon Prokupecz, and Holly Yan, "Omar Mateen Scouted Disney Complex, Pulse, Official Says," CNN, June 15, 2016, www.cnn.com/2016/06/14/us/orlando-shooter-omar-mateen/index.html.

129 Gibbons-Neff and Warrick, "Notorious Islamic State Leader Killed in Airstrike"; Dan Frosch and Nicole Hong, “Transcripts Show ISIS Influence on Orlando Gunman,” Wall Street Journal, September 27, 2016, www.wsj.com/ articles/transcripts-show-isis-influence-on-orlando-gunman-1475023090; Caitlin Doornbos, “Transcripts of 911 Calls Reveal Pulse Shooter's Terrorist Motives," Orlando Sentinel, September 23, 2016, www.orlandosentinel.com/ news/pulse-orlando-nightclub-shooting/os-911-calls-released-orlando-shooting-20170922-story.html.

130 "Pulse Nightclub Shooter Intended to Attack Disney World, Prosecutors Say," Associated Press, March 28, 2018, www.nbcnews.com/news/us-news/pulse-nightclub-shooter-intended-attack-disney-world-prosecutors-sayn860786; Alanne Orjoux, "Pulse Nightclub Gunman Omar Mateen May Have Considered Disney Properties for Mass Shooting," CNN, March 6, 2018, www.cnn.com/2018/03/06/us/pulse-shooting-mateen-scouted-othersites/index.html.

131 Perez et al., "Omar Mateen Scouted Disney Complex."

132 Frances Robles and Julie Turkewitz, "Was the Orlando Gunman Gay? The Answer Continues to Elude the FBI," New York Times, June 25, 2016, www.nytimes.com/2016/06/26/us/was-the-orlando-gunman-gay-theanswer-continues-to-elude-the-fbi.html.

133 Orjoux, "Pulse Nightclub Gunman Omar Mateen."

134 Monivette Cordeiro, "Noor Salman's Trial Gave us the Best Glimpse of What Actually Led to the Pulse Shooting," Orlando Weekly, April 3, 2018, www.orlandoweekly.com/Blogs/archives/2018/04/03/noor-salmans-trial-gaveus-the-best-glimpse-of-what-actually-led-to-the-pulse-shooting; Jack Date, Allan Lengel, and Josh Margolin, "Orlando Shooter Bought Weapons at Nearby Gun Shop," ABC News, June 13, 2016, https://abcnews. go.com/US/orlando-shooter-bought-weapons-nearby-gun-shop/story?id=39817471; Bart Jansen, "Weapons Gunman Used in Orlando Shooting Are High-Capacity, Common," USA Today, June 14, 2016, www.usatoday.com/story/news/2016/06/14/guns-used-kill-49-orlando-high-capacity-common-weapons/85887260/; Michael Daly and Shane Harris, "How the Orlando Killer Omar Mateen Got His Guns," Daily Beast, June 13, 2015, www.thedailybeast.com/how-the-orlando-killer-omar-mateen-got-his-guns; Crimesider Staff, "Gun Shop: Orlando Shooter Passed Background Check," CBS News, June 13, 2016, www.cbsnews.com/news/ 


\section{Paul Cruickshank}

gun-shop-owner-orlando-nightclub-shooter-omar-mateen-passed-background-check/; David Fleshler, "Orlando Shooter Had Passed Background Checks," Orlando Sun Sentinel, June 13, 2016, www.sun-sentinel.com/news/sflgun-shop-owner-orlando-shooting-story.html.

135 Devlin Barrett, Adam Entous, and Alan Cullison, "FBI Twice Probed Orlando Gunman," Wall Street Journal, June 13, 2016, www.wsj.com/articles/orlando-gunman-was-twice-probed-by-fbi-1465761322.

136 James B. Comey, “Update on Orlando Terrorism Investigation,” Federal Bureau of Investigation, June 13, 2016 , www. fbi.gov/news/speeches/update-on-orlando-terrorism-investigation; Massimo Calabresi, "Why the FBI Dropped Its Previous Orlando Shooter Investigations," Time Magazine, June 14, 2016, https://time.com/4368439/orlandoshooting-omar-mateen-fbi-investigation-dropped/; Wilber, "The FBI Investigated the Orlando Mass Shooter."

137 Mazzetti et al., "Omar Mateen, Twice Scrutinized by F.B.I.”; Comey, "Update on Orlando Terrorism Investigation."

138 Johnson letter to Horowitz; Calabresi, "Why the FBI Dropped Its Previous Orlando Shooter Investigations"; Wilber, "The FBI Investigated the Orlando Mass Shooter."

139 Calabresi, "Why the FBI Dropped its Previous Orlando Shooter Investigations"; Youssef and Harris, "FBI Tracked Orlando Killer."

140 Johnson letter to Horowitz.

141 Brian Ross, Gerry Wagschal and Rhonda Schwartz, “Gun Store Owner: We Alerted FBI to 'Suspicious' Customer Weeks Before Orlando Shooting," ABC News, June 16, 2016, https://abcnews.go.com/US/orlandoshooter-turned-gun-store-suspicious/story?id=39901107.

142 Johnson letter to Horowitz.

143 Calabresi, "Why the FBI Dropped Its Previous Orlando Shooter Investigations."

144 Inspectors General, Unclassified Summary of Information Handling, 23.

145 Paul Cruickshank, "A View from the CT Foxhole: An Interview with Nick Rasmussen, Director, NCTC," CTC Sentinel 8, no. 9 (2015): 5-8; Oversight of the Federal Bureau of Investigation, Committee on the Judiciary, U.S. Senate (2015) (testimony by James Comey, FBI director on December 9, 2015).

146 Comey, testimony on Oversight of the Federal Bureau of Investigation.

147 See Chart 1 in Steven Bucci, James Carafano, and Jessica Zuckerman, 60 Terrorist Plots Since 9/11: Continued Lessons in Domestic Counterterrorism (Washington, DC: Heritage Foundation, 2013).

148 Committee on Homeland Security, “Terror Threat Snapshot: April 2017” (Washington, DC: U.S. House of Representatives, 2017), 1. 